\title{
The school curriculum since apartheid: intersections of politics and policy in the South African transition
}

In the wake of South Africa's first non-racial elections in 1994, the new Minister of Education launched a national process which would purge the apartheid curriculum of its most offensive racial content and outdated, inaccurate subject matter. At a first glance these essential alterations to school syllabuses sounded reasonable and timely, given the democratic nonracial ideals of the new government. However, these syllabus alterations had little to do with changing the school curriculum and much more to do with a precarious crisis of legitimacy facing the state and education in the months following the national elections. The haste with which the state pursued a superficial cleansing of the inherited curriculum is explained in terms of the political constraints, conflicts and compromises which accompanied the South African transition from apartheid.

In August 1994 the South African Minister of Education, Sibusiso Bengu, released a series of newspaper advertisements calling for 'public comment on essential alterations to school syllabuses' (Daily News, 4 August 1994). On the face of it, this syllabus reform initiative appeared necessary, timely and transparent. However, in this paper I will argue that the syllabus alterations reflected, and deepened, a crisis within the state which had little to do with changing the school curriculum and much more to do with the politics of transition since South Africa's first nonracial, democratic elections in April 1994. After a brief orientation to the study, I begin with an analysis of the political context in which the syllabus revision project emerged, I then sketch the political process through which the syllabus revision unfolded; and I conclude with an assessment of the political consequences of this national initiative.

\section{Approach to the study}

This paper is part of a three-country research project in which I study the politics of transition as witnessed through the lens of the school curriculum (Jansen 1993, 1995). ${ }^{1}$

The theoretical literature claims that the school curriculum holds important symbolic value in transition societies (Carnoy and Samoff 1991). In this framework, curriculum reform is not primarily concerned with what it claims learning objectives, content to be covered, teaching strategies, assessment procedures, and so forth - but with addressing political constraints, conflicts and compromises in and around the state (Carison 1990). As Weiler (1990: 16) puts it:

the emphasis of many curriculum reforms on the symbolism of change and innovation.., reflects the concerns of decision-makers over the legitimacy of the decision process, and is designed to contribute, in a compensatory fashion, to the restoration of that legitimacy. 
In this paper the national syllabus revision process is explained as an act of 'compensatory legitimation' (Weiler and Gonzalez 1982, Weiler 1983, Jansen 1990 ) by a state which was increasingly vulnerable in its most volatile sector, namely education, during the immediate post-election period. This study is not, however, concerned with the details of the reforms as reflected in the new interim syllabuses for school subjects (see Mkwanazi-Twala et al. 1995). Rather, the paper assesses the political processes which initiated, governed and constrained the syllabus revision project.

The analysis is constructed on the basis of extensive interviews with national co-ordinators of the process, some of the participants in the different 'field and phase committees', and officials in education departments; and a careful review of key documents, including the series of materials produced by the National Education and Training Forum (minutes of meetings; progress reports; internal interviews; founding documents; stakeholder circulars; submissions to the Minister); the school syllabuses themselves; assessments by different stakeholders (e.g. branch reports by the South African Democratic Teachers Union); newspaper reports; and selections from the more than 800 public submissions.

\section{Origins of the initiative}

The period February 1990 (the release of Nelson Mandela and the unbanning of liberation movements) through April 1994 (the first national democratic elections in South Africa) represented a critical period of transition from apartheid. In this interregnum, a number of negotiating forums were established to manage the transition from classical apartheid towards a new political dispensation under non-racial, democratic rule. The National Education and Training Forum (NET F) was formed in late 1992 following considerable pressure to address the education crisis in a broad stakeholder forum which included the apartheid government and the extra-parliamentary organizations. The late formation of the NETF - given already established forums on drought, housing economics and health - as well as its shaky legal and political status, threatened its ability to intervene effectively in the deteriorating school system.

However, an active sub-committee of the NETF, the Curriculum Technical Sub-Committee (CTSC; then chaired by Mary Metcalfe, now political Head of Education for Gauteng Province) deliberated on the establishment of a longterm 'curriculum framework'. Since such a framework would take at least two to three years to establish, the CISC decided to consider short-term syllabus revisions as one means for intervening in the education crisis. At this point the NETF approached the Ministry of Education requesting political, logistical and financial support for a national venture which would involve a review of more than 100 school syllabuses. After long delays which lasted into the postelection period, the new Minister of Education assumed political responsibility for the national syllabus reform process.

A three-member national co-ordinating committee was formed to establish 11 'field' committees (e.g. mathematics, natural sciences, life orientation, etc.) and three 'phase' committees (junior primary, senior primary and secondary) 
with more than 30 subject committees. The brief, a focus of much contestation within the committees, was both short and vague.

The committees were to address:

- 'the factual incorrectness of subject matter' resulting from sociopolitical changes and new developments in the field of study; - content which does not reflect sensitivity to the perspectives of different groups in South Africa'; and

- 'the possible consolidation of syllabuses', given that different racial departments inherited different syllabuses for the same school subjects.

Paraphrased, the committees interpreted this brief to mean the removal of outdated, inaccurate and insensitive content from school syllabuses; and the consolidation of fragmented syllabuses. While the original stimulus for this revision was the history syllabus, this brief was now to be applied to all school subjects.

\section{The political context of the initiative}

All parties to the process (government officials, NETF coordinators, committee participants) agreed that on simple technical grounds there were compelling reasons why this syllabus revision should not have happened. First, the limited time frame: the new syllabus would have to be produced in the September-December period, ready for distribution to schools in the new academic year (January 1995). Second, curriculum development is a longterm process which involves more than a simple rearrangement of content but includes textbook revision, in-service training, assessment reform and a broad political process to generate support for, and understanding of, the proposed curriculum changes among teachers and parents.

In addition, there was an important political reason why one could have expected the process to be blocked. The leadership of the NETF in this process meant a shift in the locus of control for school curriculum initiatives from the apartheid-controlled Department of National Education (DNE) authorities - a move which any state could be expected to resist given 'the conflicting imperatives of control and legitimacy' (Weiler 1990). Yet, despite these constraints, the Minister insisted on 'the most essential changes to syllabuses as quickly as possible [which] should not make it necessary to introduce new textbooks' (Daily News 4 August 1994). The question is clear. Why would a Minister of the majority in a government of National Unity stake his reputation on, and lend support to, a bland and minimalist reform of the apartheid curriculum?

I propose that the explanation for this reformist initiative lies in the emergence of two conflicting pressures on the state in the post-election period, pressures exacerbated by poor, compromised and divided leadership in the nascent Ministry of Education during 1994.

First, consistent, negative media publicity placed considerable pressure on 
the Ministry of Education. The Weekly Mail and Guardian published a deeply critical report on the 'Ministry of Paralysis' - an unfortunate play on words given the recent stroke suffered by Minister Bengu. Problems cited include the weak political credentials of the Minister, a relatively unknown national figure in the African National Congress; the entrenched power of the old education bureaucrats; the political indecisiveness of the Minister - an assessment fortified by the decisive political leadership by Steve Tshwete in his acting role as Minister of Education during Bengu's illness; the education policy credentials of the Minister who, by his own admission, was not involved in the dynamic policy debates within the democratic movement since 1990; and the slow pace of securing full-time permanent appointments from outside the bureaucracy, including the Director-Generalship (Weekly Mail and Guardian, 22 - 28 July 1994: 10). An even more critical review emerged in the influential Financial Mail (25 November 1994) which, on its front cover, portrayed Minister Bengu as the Pied Piper of Hamelin leading children to their doom. A third and unsettling assessment came from media comparisons which asked quite simply: 'Why could Housing..., Health... or even the lowly Water Affairs... Ministries act to sideline old bureaucrats and generate groundbreaking social policies in similar environments to those inherited by Bengu?'2 In its review of 'The First 100 Days', the Financial Mail (19 August 1994: 23) issued a blunt assessment and warning:

it is said, and it is even dangerous, that two of the most important portfolios [i.e. Education and Health] are in uninspired hands. At education, Sibusiso Bengu has even been criticized openly by the ANC-aligned National Education Crisis Committee for his lack of progress ... if his stroke has incapacitated him, he should resign.

But the National Education Co-ordination Committee (NECC) assessment was the most damaging; under increasing pressure from its own constituency, the committee called a hastily prepared news conference questioning the Ministry of Education on its lack of visible changes in the education system. And the NETF itself in a 'Circular to Stakeholders' records its executive notice to senior Department of Education officials on 'concerns relating to the perceived lack of change in education' (Sonn 1994:1).

Media pressure mounted and in August 1994 Minister Bengu (Ministry of Education and Training 1994:2) conceded to a Kwa-Zulu Natal meeting of supporters that:

We have been getting I [sic] a lot of criticism both in the media and from within our own organization about fundamentals of progress in bringing about fundamental change in education.

In the same speech the Minister announced the formation of 'A subcommittee on curriculum' as concrete evidence of action. After that point the media was 
fed a steady stream of briefings on the curriculum activities (Star, 19 October 1994, 24 October 1994). The Minister also made space in the Draft White Paper on Education and Training to signal his support for 'the process of curriculum change which has been developed, with the cooperation of the Department of Education, by the NETF Committee' (Department of Education 1994: 15). It was clear that the syllabus revision process was the single most visible national intervention $b$ the Minister in the education sector in the months following the election ${ }^{3}$.

A second and conflicting set of pressures was the clearly intractable package of problems inherited by the Ministry and its bureaucratic arm, the Department of National Education (DNE). First, the elaborate, clumsy and dispersed nature of the education bureaucracy with its nineteen education departments was unique in the public sector. Second, the formal arrangements laid down in the constitution protected mainly white civil servant positions from the postapartheid government. Third, the informal arrangements generated by the politics of reconciliation, and championed by President Mandela, further weakened radical decision- making in education. Fourth, the Public Services Commission, a conservative bureaucratic apparatus, consciously slowed down the nature and pace of new appointments. Fifth, the relative autonomy of the provinces would limit the intervention and authority of the National Ministry. Sixth, the powerful lobby of the white education constituency would directly and through political parties press for the status quo as it affected all education matters, including curriculum. Seventh, and most important, the political readiness of the Minister to interpret these constraints as real - rather than subject to strategic intervention - supported the emergence of a minimalist reform position on all education matters, including the school curriculum.

\section{The process: what happened?}

Within this context, an intensive process of syllabus revision started throughout the country in late August 1994. Early meetings of the committees were characterized by intense struggles for voice, representation and meaning around the ministerial brief. Two examples should suffice. One such struggle involved the 'secretariat' for the process - a position offered to the committees by the DNE which, through its officials, soon assumed a guiding voice in the different committees. This generated resentment among some participants who saw these committees as broad stakeholder forums rather than simple government structures. The complaint raised by a South African Democratic Teachers Union (SADTU) representative on one of the committees was not an isolated one; it also provides insights into struggles for political authority and voice in these committees:

Initially there were problems with the secretary ... in that he constantly made input, thus giving the DNE an additional voice. Fortunately, this matter was attended to at an early stage and the Chairman... ensured 
that the Secretary did not exercise an undue influence on the proceedings.

Another set of struggles revolved around the interpretation of the brief. In the Science Committee, for example, a large proportion of meeting time was absorbed in discussions as to whether 'The Creator Clause' in these syllabuses should be removed. All science syllabuses declared the following objective:

that the child become aware of the majesty of creation through his acquaintance with the wonder and order of Creation... in this way develop a sense of awe and reverence of the Creator.

Some members argued that this clause would interfere with the teaching of evolution and was part of the conservative Christian National Education philosophy. According to the field committee report to the Department, 'All agreed that the removal of the clause was merely symbolic as it did not in fact impinge on what went on in science classrooms.' Yet, despite the symbolic value of the proposed change, this clause became the focal point of deliberations in some science committees because of its broader relationship to conservative politics. No consensus was reached on this matter. This was not, however, a process unfolded in isolation of a series of interlocking mechanisms which ensured state control of the syllabus process. First, the senior bureaucrats from the ex-DNE retained final political editorship of the process, one which would ensure a narrow, technical and limited interpretation of the brief. At various stages substantial syllabus documentation was reduced to comply with a 'barebones' interpretation of the brief; in history, a legal investigation has been underway to determine how decisions made jointly about syllabus revisions was scuttled by conservative individuals editing out the agreements (Weekly Mail and Guardian 1-7 July 1995). Second, the matriculation subject syllabuses had to be approved by the Committee of University Principals, another intervening influence in the bureaucratic process. And third, the provincial government departments - still largely controlled by apartheid's bureaucrats - would serve as yet another political filter in the process of 'provincialization' of school syllabuses. A clear recognition of such editing was raised and conceded in an NETF meeting. One delegate warned about 'a minimization or "watering down" of the [committee's] recommendations' to which one of the three coordinators responded that changes 'could in any event only be presented to provinces as recommendations, and how such was taken forward was a provincial prerogative' (NETF 1995).

In the end, the subject syllabuses reviewed by the NETF committees reflected three main outcomes:

- non-change some syllabuses remained completely unchanged, e.g. African languages, 'because the existing syllabuses are so flawed that 
tampering would be futile' (NETF 1994d).

- editorial adjustments some syllabuses simply added an introductory

overview, e.g. English, for which a 'communicative approach' was encouraged; or accounting, which involved terminological adjustments such as 'changing from GST (General Sales Tax) to VAT (Value Added Tax)'.

- topical reshuffling some syllabuses added new topics and scaled down others, e.g. history, which de-emphasized European history and expanded 'African Nationalism'.

More seriously, several of the changed syllabuses simply reflected the existing House of Assembly (that is, the white political establishment for education) syllabuses, thereby reinforcing and legitimizing the white education model of curriculum. In other cases,

the new syllabuses represent a fusion of the core curricula of the old ethnic departments, which in itself is possibly the worst basis from which to introduce any progressive syllabus... Thus the point of departure [i.e. the brief] largely determined the outcome and defeated the purpose of presenting improved syllabuses. ('New history syllabuses' 1995: 4)

\section{The process: what consequences?}

Several participants in the process, at all levels, enumerated the same perceived benefits from the syllabus revision activity. First, it is claimed that the process 'created expertise' among those traditionally excluded from curriculum development. Second, the process legitimized state-led curriculum initiatives given the broad base of participation in the committees. Third, the process enabled a working relationship between government and historical opponents on matters of common concern.

While generally accurate, some of these claims are exaggerated: few students actually participated in the process despite being accorded formal representation; few teachers could lead the process given the lack of skills in curriculum matters and the involvement of teachers with full-time teaching commitments; the dominant, shaping voices in these committees were mainly white and male, and the committees functioned largely as insular groups having little systematic connection to the broad base of teachers and students. As one committee representative put it, there was 'no mechanism to abet the process of feedback to structures "on the ground" (SADTU 1995d). The more serious consequences of the process are political in nature ${ }^{4}$. The process procured short-term political legitimacy for a crippled Ministry without having to demonstrate the need for substantial change. The process further deflated the demand for immediate, fundamental change to the school syllabuses. In the words of one of the national co-ordinators:

'this reformist exercise has delayed the possibilities of real transformation'. 
And third, the process set in place, and consolidated, a pattern of curriculum change which is context-blind, i.e. de-linked from the dynamics and complexities of school and classroom contexts, teacher development and support, systematic assessment reform, genuine grassroots participation, and textbook development. The way in which most provinces recently introduced 'continuous assessment' is a case in point. The process has generated a public understanding that minimalist revisions to school subjects are both acceptable and workable.

It will be extremely difficult in the future to change such expectations beyond the reshuffling of syllabus topics towards a national curriculum which challenges the fundamental philosophical and ideological roots of apartheid education. A most perceptive analysis of this political dilemma was provided by a teacher representative in one of the committees, and is worth quoting at length:

Curriculum change does not happen overnight and at the rate we are going in South Africa the real danger is that we will be weighed down the burden of reformed Christian National Education for a long time ... The bureaucrats are quite happy to pass off subject revisions as curriculum change because it does not even begin to rock their boat. In fact they are enthused by it all as they now have an opportunity to gain legitimacy in schools as being part of the new which is really the old (SADTU 1995h).

Not only was the status quo retained, but some argued that existing proposals for continuation of curriculum development after 1995 'will entrench the position of the DNE core syllabus committees... a procedure which could well hinder the advance of equitable and progressive curriculum development' (Gordon 1994: 1). Indeed, the ex-DNE officials are at pains to stress the consistency of the 1994 syllabus revision process with past curriculum work under the apartheid government as well as its continuity with future plans led by resurrected provincial committees of the past (Department of National Education 1995). Current struggles over the future of the proposed ' 41 committees' in relation to the African National Congress-proposed National Institute for Curriculum Development is really a struggle over who controls curriculum and, by extension, the vision of the social order which it represents.

\section{The triumph of conservative politics}

To read the NETF process as a mere technical event concerned with syllabus revisions is to limit understanding of the pace, direction and content of these changes. By assessing the process through the lens of political transition enables understanding of both the state and curriculum reform in the postelection period. Using the construct of 'compensatory legitimation', the four main conclusions of this paper can be re-stated. 
First, the syllabus revision process must be understood in the context of the constitutional and bureaucratic constraints of political transition under a Government of National Unity. These constraints were powerfully felt in the Ministry of Education.

Second, the syllabus revision process emerged in the context of weak and vulnerable political leadership in the Ministry of Education. That is, a leadership which failed to translate political constraints into strategic opportunities for educational transformation.

Third, the syllabus revision was propelled by mounting pressure on the Ministry of Education from the media, allied ANC constituencies, and the broad public for intervention in the education crisis. In order to compensate for a lack of visible, durable and long-term changes in the education sector, the minimalist syllabus reform process provided the Minister (and government) with important political breathing space in the early days of transition ${ }^{5}$. Fourth, the syllabus revision process was made possible by a weak political challenge from the educational community on the educational terms of this project. In fact, the participation of most teacher bodies from across the political spectrum further compensated for the loss of legitimacy suffered by the Ministry of Education in the latter half of 1994 and its predecessors under the apartheid government.

To conclude, this process was not about curriculum. It was about legitimizing a vulnerable Ministry of Education which lacked the political will to re-direct educational and curriculum policies to reflect the broad visions for alternative education which had mobilized political struggle in the past three decades and more. With striking consistency, all key participants justified participation in the process with the simple rationale:

'something had to be done'.

This is not to suggest that a democratic curriculum process would unfold along a linear, unproblematic political trajectory; the terms of South Africa's transition demanded compromises, conflict, consensus and contradictions. It does suggest, however, that in a Ministry in which the key incoming leadership sees its primary role as bureaucratic rather than political, as placatory rather than interventionist, as legalistic rather than strategic, conservative politics will triumph without the need for much exertion. In this early but critical period of the South African transition, the proverbial 'balance of forces' was firmly entrenched in favour of the apartheid curriculum and its settled bureaucrats. And this is unlikely to change beyond 'essential alterations ${ }^{\prime 6}$.

\section{Acknowledgement}

An earlier draft of this paper was delivered to the annual meeting of the Teachers League of South Africa, July 1995. I am grateful to the teachers at this conference for their valuable comments on the presentation. 


\section{Notes}

1. Such an understanding of the political interests shaping curriculum reform is now the subject of an established literature in the field of curriculum studies (see, for example, Apple and Beyer 1990, Weiler 1990, Pinar and Bowers 1992, Apple 1993.

2. See 'School policy: Bengu bungles on', Financial Mail, 25 November 1994: 22.

3. Despite the syllabus reforms, the media continues to write of the lack of educational changes at national and provincial levels; see 'Education: something must give', Financial Mail, 4 August 1995.

4. For some of the pedagogical consequences of the syllabus revision process, see Green- stein and Mabogoane (1994) and 'English Second Language Interim Syllabus' (1995).

5. One of the ambiguities which persisted in this process concerned the leadership of the syllabus revision project. At times the political roles of the NETF co-ordinators appeared to clash with those of the Minister and his colleagues. One critical incident was the calling of a press conference by the co-ordinators to report their preliminary findings. This event outraged the Minister, who clearly felt that the political credits from the process should be located firmly within his Ministry.

6. A separate study is required on the political language of educational reform in South Africa Architectural or building metaphors such as 'alterations' or 'rehabilitation' suggest an add-on, evolutionary and 'patch-up' reform process rather than one which is radical or fundamental in scope - despite the idealistic visions of activists in the pre-election period. For general readings on 'political language', see Edelman (1975).

\section{References}

AWLE, M W. (1993) Official Knowledge (New York: Routledge).

AWLE, M W. and L (1990) The Curriculum. Problems, Politics, Possibilities

(Albany: SUNY Press).

CARLSON, D. (1990) Curriculum planning and the state. In M. W. Apple and

L. E. Beyer (eds), The Curriculum Problems Politics and Possibilities (Albany: SUNY Press), 35-47.

CARNOY, M and SAMOFF, J. (1991) Education and Social Transition in the Third World (Princeton: Princeton University Press).

COMMITTEE OF HEADS OF EDUCATION DEPARTMENT (CHED) INTERIM CHED (1994) Reports of Field and Phase Committees, 17 October 1994, Annex P.

DEPARTMENT OF NATIONAL EDUCATION (1995) Curriculum Development Initiatives at National Level (Pretoria: Department of National Education). DEPARTMENT OF NATIONAL EDUCATION (1994) Draft white paper on education and training, Government Gazette, 351(15974), 23 September. EDELMAN, M. (1975) Political Language: Words that Succeed and Politics that Fail (New York: Academic Press). 
ENGLISH SECOND LANGUAGE INTERIM SYLLABUS (1995) Education Journal, 65(3), 7-9, 12.

GORDON, A. (1994) Memorandum Curriculum Development and Pilot

Projects Following the NETF and Department of Education Field and Phase

Process, 12 December (Johannesburg: National Education and Training

Forum).

GREENSTEIN, R and MABOGOANE, T. (1994) The challenges of

transformation: policy and conflict in South African education and training.

EPU Quarterly Review of Education and Training in South Africa, 2(2), 1-35.

JANSEN, J. D. (1990) Curriculum policy as compensatory legitimation? a view from the periphery. Oxford Review of Education, 16(1), 29-38.

JANSEN, J. D. (1993) Curriculum reform in Zimbabwe: reflections for the South African transition. In N. Taylor (ed.), Inventing Knowledge: Contests in Curriculum Construction (Cape Town: Maskew Miller Longman), 58-68.

JANSEN, J. D. (1995) Understanding transition through the lens of curriculum policy: Namibia, 1990-1994. Journal of Curriculum Studies, 27(3), 245-261. MKWANAZI-TWALA, Z., MWIRIA, Z.K. and GREENSTEIN, R. (1995) The ongoing process of change: policy and conflict in South African education and training. EPU Quarterly Review of Education Training in South Africa, 2(3), 143.

MINISTRY OF EDUCATION AND TRAINING (1994) Minister's Input: Speech in Durban on 13/08/1994 (Pretoria: Ministry of Education and Training).

NATIONAL EDUCATION AND TRAINING FORUM (NETF)(1994a)

Establishment, Compositions, and Functions of the National Curriculum

Committees. Document A (Johannesburg: NETF), 1-5.

NATIONAL EDUCATION AND TRAINING FORUM (NETF) (1994b) Synopsis of general changes in the second phase as well as the changes to following fields of school subjects: Life Orientation, Computer Studies, Mathematics and Natural Sciences. In National Education and Training Forum Reports in Document F (Johannesburg: NETF), 1-9.

NATIONAL EDUCATION AND TRAINING FORUM (NETF) (1994c) Synopsis of general changes in the following fields: Agriculture, Economic Sciences, Engineering and Junior Primary. In National Education and Training Forum Reports in Document F (Johannesburg: NETF), 5-10.

NATIONAL EDUCATION AND TRAINING FORUM (NETF) (1994d) Summary of Changes to the Language, History and Geography Syllabuses. In National Education and Training Forum Reports in Document F (Johannesburg: NETF), 11-12.

NATIONAL EDUCATION AND TRAINING FORUM (NETF) (1995) Curriculum Technical Sub-Committee: Agenda and recommendations, tabled at meeting of 27 March 1995, Document B (Johannesburg: NETF).

'New history syllabuses for std 2-5: comparison with previous syllabus' (1995) Education Journal, 65(2), 3, 4, 11.

PINAR, W. F. and BOWERS, C. A. (1992) Politics of curriculum origins, controversies and significance of cultural perspectives. In Gerald Grant (ed.), Review of Research in Education, 18 (Washington, DC: American Educational Research Association), 163-190

South African Democratic Teachers Union (SADTU) (1995a) Reports in Document C: Report by the Secondary Phase Representative on the First Phase of Curriculum Transformation, 28 February, Ladysmith. 
South African Democratic Teachers Union (SADTU) (1995b) Reports in Document C: Report of the Phase and Field Review Committee, 3 March, Nelspruit

South African Democratic Teachers Union (SADTU)(1995c) Reports in Document C: Report, Midlands Region Education Desk, undated.

South African Democratic Teachers Union (SADTU) (1995d) Reports in Document C: Report to National Education Committee from Convenor: Mathematics Field Committee, 27 February.

South African Democratic Teachers Union (SADTU) (1995e) Reports in Document C: Report, Western Cape History Sub-Committee, 3 March. South African Democratic Teachers Union (SADTU) (1995f) Reports in Document C: Report, Western Cape Guidance and Counselling SubCommittee, 2 March.

South African Democratic Teachers Union (SADTU) (1995g) Reports in Document C: Report on the Junior Primary Phase Committee, 26 February. South African Democratic Teachers Union (SADTU) (1995h) Reports in Document C: Report by Regional Education and Development Committee, Western Cape Province.

South African Democratic Teachers Union (SADTU) (1995i) Reports in Document C: Report by Computer Science Sub-Committee, 3 March. SONN, F. (1994, August) Circular to Stakeholders (Johannesburg: National Education and Training Forum).

WEILER, H. (1983) Legalization, expertise, and participation: strategies of compensatory legitimation in educational policy. Comparative Education Review, 27(2), 259-277.

WEILER, H. (1990) Curriculum reform and the legitimation of educational objectives. Oxford Review of Education, 16(1), 15-27.

WEILER, H. and GONZALEZ, H (1982) Compensatory legitimation: exploring the utility of the construct for the comparative study of educational policy.

Paper prepared for the annual meeting of the Comparative and International Education Society, New York (Graduate School of Education, Stanford University, Palo Alto). 